\title{
Erdei Gábor
}

\section{TANULÁS MINDENHOL ÉS MINDENKOR? \\ Avagy mit is mond a tanulásról a Classification of Learning Activities (CLA) Eurostat kézikönyv'}

\section{DOI 10.35402/kek.2019.1.8}

Az Eurostat 2016-ban megjelentett kézikönyve a tanulási tevékenységek osztályozására vállalkozott (Classification of Learning Activites, CLA). Nem előzmények nélküli ez, hiszen az Unió létrejötte, a Lisszaboni Csúcstalálkozón megfogalmazott globális versenyképesség, az 1990-es évek információrobbanása, a globalizáció és hálózatosodás erősödése, a tudás-intenzív gazdaságok dominanciája az oktatás, a képzés és tanulás szerepének újragondolására késztette az Unió vezetőit, de egyben az uniós állampolgárt is.

Erre az időszakra tehető az LLL szemlélet és szakpolitika megerősödése is. Amennyire könnyen megragadhatók a közoktatásban és a felsőoktatásban megvalósuló tanulások statisztikákkal, annál nehézkesebbek, bizonytalanabbak a felnőttkori tanulások mérésére életre hívott mérőeszközök. S miközben megvalósult a paradigmaváltás: az LLL szemléletben az oktatás egyeduralma megszűnt és a tanulások szerepe erősödött meg, a jelenséget (ti. tanulási tevékenységeket) megragadni szándékozó módszerek nem tudták és nem tudják ezt az igényt maradéktalanul kiszolgálni. Ahogyan a tradicionális megközelítésben a tanulás és tudás kapcsán jellemzően az oktatási, képzési intézményekre asszociáltak az érintettek, a paradigmaváltás új tanulási terepeket, formákat hívott életre. Nem mintha eddig nem léteztek volna, azonban szerepük hangsúlyosabbá vált.

Az LLL megközelítésben nem egyszerűen arról van szó, hogy a személyiségfejlesztés, az oktatás, képzés és tanulás egyre markánsabban kitart, és újra és újra megjelenik a felnőttkorban, hanem arról is, hogy e jelenségekhez kapcsolódó oktatási, képzési, tanulási formák, folyamatok, módszerek, tartalmak és irányok is átalakulnak.

Az első CLA kiadvány 2006-ban jelent meg. Azonban az azóta eltelt időszak több területen is továbbgondolásra késztette a kiadvány szerkesztőit.

A Bevezető rész a Kézikönyv létrejöttét, ennek szükségszerüségét taglalja, azt, hogy miért is van

1 European Union 2016 Classification of learning activities (CLA). Manual, 2016 edition. Manulas and guidelines. Eurostat. Publications Office of the European Union, Luxembourg. szükség a tanulási tevékenységek osztályozására. A fejlesztési politikával, szakpolitikával foglalkozó szakértők számára a statisztikák nélkülözhetetlen alapot jelentek szakmai tevékenységük megvalósítására. Éppen ezért, a tanulási tevékenységek osztályozása megkerülhetetlen eszköze az életen át tartó tanulás mérésének. A CLA konkrétan 2002-ben került megfogalmazásra és létrehozásnak szükségességet a „hiányokkal” magyarázták (a fogalom tisztázásnak hiánya, koncepciók hiánya, mérőeszközök, módszerek hiánya stb.). A terv sikerességéhez az UNESCO két intézetét is bevonták (ILO, UIS). A munkafázis lezárását követően a szakértői csoportok hangsúlyozták, hogy a leendő CLA egyetemesnek, minden országban és kultúrában használhatónak kell lennie, másfelől képesnek kell lennie arra is, hogy mindenféle tanulást megragadjon. A CLA inputot biztosít a három jelentős felnőttkori tanulást vizsgáló statisztikai rendszernek is (AES, LFS, CVTS).

A terjedelmesebb első fejezet ismerteti a koncepciókat és a definíciókat: lifelong learning; tanulási aktivitás versus nem tanulási aktivitás; formális oktatás és képzés; nem formális oktatás és képzés; informális tanulás. A fejezet megadja a szempontokat is, amelyek ezeket a nagy kategóriákat elkülöníti egymástól.

Kiemelnénk a lifelong learning definíciójának egy elemét. A Kézikönyv szerint az LLL-be tartózó tanulásoknak tudatosnak kell lenniük. Vagyis nem tartozhat ebbe a kategóriába a véletlenszerü, spontán kialakuló tanulás (pl. családi, munkahelyi beszélgetés során megjelenő tanulás). Ez figyelemre méltó megközelítés, annál is inkább, hiszen több kutató (pl. Merriam és Brockett 1997) is kifejti azon nézetét, miszerint a LLL legerősebb oszlopa éppen az informális tanulás, amelynek jelentős része nem szándékoltan (spontán módon) jelenik meg. Ugyanakkor a Kézikönyv a későbbiek során önálló tanulási kategóriába sorolja a véletlenszerü tanulást (de nem sorolja LLL tevékenységek közé). Éppen ezért - fontosnak tartjuk hangsúlyozni - a CLA nem is vizsgálja ezt tanulási tevékenységet.

Ennélfogva a tanulási tevékenység versus nem tanulási tevékenység megközelítésben elsősorban 
a szándékosság a vízválasztó. A megközelítés nem tekinti tanulási tevékenységnek a nem szándékos tevékenységet, vagyis az egyénben csak az elöre megfogalmazott tevékenység kerülhet a tanulási tevékenység kategóriába. A Kézikönyv ezzel a megközelítéssel tulajdonképpen az információ és a tanulás között húzódó különbséget is feszegeti. A Kézikönyv példaként a sportot említi. Amíg a sportban egy sportesemény például egy edző által irányított tevékenységként jelenik meg, addig tanulásként értelmezhetjük a tevékenységet, azonban a tanulást nem szolgáló játék (egy baráti focimeccs) már kívül esik a tanulás kategóriáján és rekreációnak tekintheto".

A második fejezet tárgyalja a tanulási tevékenységek osztályozását. A Kézikönyv egy példával illusztrálta a tanulási tevékenységek osztályozásnak problémáját: a formális oktatás létrehozhat nem formális oktatást és informális tanulást is. Valójában nem ez okoz problémát, hanem az, hogy a CLA az egy önmagában álló tanulási tevékenységet („single learning activity”) veszi vizsgálati egységének alapjául. S tekintettel arra, hogy a formálisabb rendszerekhez köthető tanulásokat magasabb rendűként értelmezi, így a formális oktatásokhoz kapcsolódó - hierarchia szempontjából „alacsonyabbnak" tartott - nem formális és informális tanulás megjelentetése nehézségekbe ütközik. Vagyis egy iskolai óra által meghatározott házi feladathoz kapcsolódó magántanár segítség, vagy szintén ehhez kapcsolódó tanulói autodidaxis a CLA rendszerben a „magasabbnak” számító formális oktatásban nyer értelmezést (s egyben statisztikai megjelenést), mert ehhez kapcsolódik. Ugyanakkor, ha a magántanári segítség rendszeresen jelen van, akkor azt külön tanulási tevékenységként szükséges értelmezni.

A harmadik, rövidebb fejezet mutatja be a CLA struktúrát, egymásra építve a nagy kategóriákat, ezek alábontásában az osztályokat, majd az alosztályokat. Ennek során a Kézikönyv minden egyes tanulási tevékenységet rendszerszerűen leír, definiál, a kivételeket értelmezi. Ez a rész igazi kézikönyvként szolgál, hiszen ha az érdeklődő az esetleges tanulási tevékenység vonatkozásában, kategorizálásában bizonytalan, felüti a kiadványt és megtalálja az általa vizsgált tanulási tevékenységet a vázolt rendszerben és mellé a leírást is az adott tanulási tevékenységről.

$\mathrm{Az}$ irodalomjegyzékben megjelennek azok a globális nemzetközi szervezetek (UNESCO, World Bank, OECD, CEDEFOP), amelyek szintén foglalkoznak az oktatás és képzés világával, a tanuláshoz kapcsolódó fogalmak és tevékenységek értelmezésével.

A Kézikönyv egyértelmű erőssége, egyben újszerủ megközelítése a mellékletben található, ahol a tanulási tevékenységek gyakorlati példákkal való szemléltetését nyújtja. A 95 esetleírást bemutató példa minden lehetséges tanulási kategóriát világosan ismertet.

Nem gondoljuk azt, hogy ezen alapos, körültekintően összeállított Kézikönyv megoldja az összes, a témában felmerülő kérdést, bizonytalanságot sőt magunk is vitatkozunk egy-két értelmezésével, megközelítésével -, de az kétségtelen, hogy világosan, rendszerszerűen kalauzolja az olvasót az oktatás, képzés, tanulás taxonómiájában.

A kiadvány ajánlható olyan szakemberek, kutatók, statisztikusok, gyakorlati megvalósítók és érdeklődők számára, akik a permanens művelődés, a tanuló társadalom, a tanulás-vezérelt gazdaság világában élve szorosabban kapcsolódnak az emberi tevékenységek e speciális, és talán egyik legfontosabb világához.

\section{Felhasznált irodalom}

Merriam, Sharan B. - Brockett, Ralph G. 1997 The Profession and Practice of Adult Education. An Introduction. CA Jossey-Bass, San Francisco. 